DOI: https://doi.org/10.32839/2304-5809/2021-4-92-18

УДК 327:17.022.1(1-4)

Хмель А.О., Мещерякова А.В.

Чорноморський національний університет імені Петра Могили

\title{
ЗОВНІШНЬОПОЛІТИЧНИЙ ІМІДЖ КРАЇНИ: ТЕХНОЛОГІЇ ФОРМУВАННЯ
}

\begin{abstract}
Анотація. Протягом тривалої історії міжнародних відносин найважливішим фактором для сприйняття країни на міжнародній арені, ставлення до неї та встановлення/налагодження/розірвання відносин із нею був і залишається зовнішньополітичний імідж. Але на сьогодні зовнішньополітичний імідж держави стає ще більш важливим чинником, що визначає їі політичну і економічну конкурентоспроможність на міжнародній арені, стає їі сильною або слабкою стороною, яку впізнає світ і яку вкрай важко змінити, адже такий процес може зайняти багато часу та бути вкрай коштовним. Звертаючи увагу на той момент, що окрім самої країни її імідж за допомогою бурхливого розвитку ЗМК на початку ХХІ ст. можуть зіпсувати або змінити інші країни (прикладами чого можуть бути російські 3МI в Європі, які прагнули сфрормувати негативне сприйняття подій Револющії в Україні 2014 року та спотворили сприйняття російської агресії на Сході, перетворивши їх у «громадянську війну» на своїх шпальтах), фрормування та підтримування іміджу є вкрай важливим елементом зовнішньої політики, який має підтримуватися та забезпечуватися централізовано самою країною. Тож технології формування зовнішньополітичного іміджу країни є тему актуальною. 3 огляду на це, автори поставили собі за мету виявити, проаналізувати та висвітлити аспекти формування зовнішнього і внутрішнього іміджу країни і методи його поліпшення. Протягом дослідження, автори прийшли до висновку що існує велика кількість фракторів, що впливають на зовнішньополітичний імідж країн : природно-ресурсний потенціал, соціологічні фрактори впливу та інституційні фактори (імідж представника держави, якість та стиль проведення зовнішньої та внутрішньої політики, політика урядів щодо вирішення глобальних проблем). Загального алгоритму, тобто схеми, яка б надала чіткі та стандартні вказівки кожній країні у побудові свого зовнішньополітичного іміджу - не існує, адже кожна країна має свої висхідні параметри: зовнішні і внутрішні чинники, які впливають на фрормування іміджу. Але стандартними можуть бути етапи розробки іміджевої політики держави (за Т. Грінбергом): оцінка ситуащї (на яку аудиторію розраховано і який імідж та образи вже сформовані); позиціонування (пошук та демонстрації відмінної, індивідуальної переваги); вибір та розробка комунікативних стратегій просування характеристик іміджу.
\end{abstract}

Ключові слова: зовнішньополітичний імідж, міжнародні відносини, іміджелогія, іміджмейкінг.

Khmel Anastasiia, Meshcheriakova Anastasia

Petro Mohyla Black Sea National University

\section{FOREIGN POLICY IMAGE OF A STATE: FORMATION TECHNOLOGIES}

Summary. Throughout the long history of international relations, the most important factor for the perception of the country in the international arena, attitude to it and the establishment / building / severance of relations with it has been and remains the foreign policy image. But today the foreign policy image of the state becomes an even more important factor that determines its political and economic competitiveness in the international arena, becomes its strength or weakness, which the world recognizes and which is extremely difficult to change, because such a process can take time and be extremely costly. Paying attention to the fact that in addition to the country itself, its image through the rapid development of WMC in the early XXI century. can spoil or change other countries (examples of which are the Russian media in Europe, which sought to form a negative perception of the events of the Revolution in Ukraine in 2014 and distorted the perception of Russian aggression in the East, turning them into a "civil war" in their columns), forming and maintaining image is an extremely important element of foreign policy, which should be supported and provided centrally by the country itself. Therefore, the technology of forming the country's foreign policy image is a topical issue. With this in mind, the authors set themselves the goal to identify, analyze and highlight aspects of the formation of external and internal image of the country and methods of improving it. During the research, the authors concluded that there are a large number of factors influencing the foreign policy image of countries: natural resource potential, sociological factors and institutional factors (image of the state, quality and style of foreign and domestic policy, government policy to address global problems). There is no general algorithm, ie a scheme that would provide clear and standard instructions to each country in building its foreign policy image, because each country has its own ascending parameters: external and internal factors that affect the formation of the image. But the standard stages can be the development of the image policy of the state (according to T. Greenberg): assessment of the situation (for which audience it is intended and which image and images have already been formed); positioning (search and demonstration of excellent, individual advantage); selection and development of communicative strategies to promote image characteristics.

Keywords: foreign policy image, international relations, imageology, image-making.

$\Pi^{2}$ остановка проблеми. 3 XX століття, особливо в епоху холодної війни, уряди усвідомлювали значення безперервного фpopмування та підтримування іміджу. В XXI ст., 3 настанням глобалізованої комунікації спостерігається сплеск побудови національного іміджу.
Поточне опікування побудовою іміджу може виконувати подвійну функщію, якщо буде проводитись ефективно: створити внутрішню політичну підтримку, та збільшити міжнародний вплив країни. Остання фрункція сьогодні вважається більш актуальною, оскільки країни прагнуть 
інтегруватися до світових ринків, брати участь у глобальних справах та підвищувати свій статус на світовій арені. Те, як країну сприймають та прогнозують інші країни, може призвести до змін у їхніх взаєминах та стратегічних реакціях Привабливий ж імідж держави забезпечуе їй цілий ряд конкурентних переваг: сприяє залученню туристів, створює сприятливий клімат для інвестування в економіку, науку, освіту, сприяе налагодженню контактів у всіх сфрерах суспільного і культурного благополуччя громадян, фрормує позитивний психологічний настрій суспільства в цілому. Негативний імідж країни може сприяти відстороненню від неї, її ігнорування (коли це можливо), ізоляцію. Тому технології формування зовнішньополітичного іміджу країни є актуальною та корисною сфрерою дослідження.

Виділення нерозв'язаних частин раніше частин загальної проблеми. Зважаючи на той аспект, що досліджені нами наукові надбання в галузі імеджелогії стосувалися або взагалі теми іміджу (як людини так і країни) або складових іміджу української держави (наприклад, рід час російської агресії), то виявлення загальних технологій побудови зовнішньополітичного іміджу країни в сучасних умовах глобалізованого світу все ще залишаеться актуальним.

Аналіз останніх досліджень і публікацій. Варто зазначити, що зважаючи на важливість теми, нею опікуються сучасні науковці і вже здійснено ряд досліджень. Зокрема, даною темою почалися займатися ще в радянські часи такі українські та російські теоретики іміджелогії, як А. Панасюк, Г. Почепцов, В. Шепель. Питання іміджелогії розглядаються у виданнях, присвячених діловому спілкуванню або діловому етикету. Особливо слід відзначити роботи таких авторів: М. Бурліна [2], М. Лебедєва [3], Н. Ушакова та А. Стрижова [5] та інші.

Серед українських дослідників слід виділити Г. Почепцова із працею «Іміджелогія». Внесок у становлення іміджелогії також належить Н. Барні [1], яка у своєї праці розкрила питання іміджмейкінгу, та як побудувати ефективний імідж. Варто відзначити I. Пантелейчука, який досліджуе роль зв'язків з громадськістю у формуванні іміджу державних інституцій та розкриває окремі аспекти фрормування та розвитку іміджу серед державних інституцій [9]. Крім іншого, питання політичного іміджу України досліджували: А. Осмоловська [7], Г. Піскорська та А. Яковенко [11], О. Омельченко [8], а технології форомування зовнішньополітичного іміджу країни досліджували П. Петров [10] та О. Чечель [13] .

До західних вчених, що розглядали питання іміджу держав слід віднести Дж. Уелша, С. Анхолта, Л. Беннета, Д.Х. Вівера, Дж.К. Вілхейта, К. Болдуіна [14-20]. Дані дослідники визначали аспекти створення зовнішньополітичного іміджу, а також як засоби масової інформації впливають на сприйняття корпоративної репутації.

В той саме час не всі сторони формування міжнародного іміджу країни розкриті в роботі вищезазначених авторів, що і робить наше дослідження актуальним. Крім того, актуальність роботи відзначає той фракт, що українські фрахівці у своїх працях фріксують відсутність чітко сформульованої та послідовної іміджевої політики України, що зводилася б насамперед до однозначно прийнятої усіма верствами та прошарками суспільства національної ідеї [6].

Метою статті є: проаналізувати й систематизувати набутки дослідників в галузі технологій побудови зовнішньополітичного іміджу країни та виявити технології, які сприяють формуванню зовнішньополітичного іміджу країни в актуальних обставинах.

Виклад основного матеріалу. Під іміджем країни розуміеться сукупність уявлень про країну. Незважаючи на те, що держави в усі часи прагнули якомога краще представити себе світовій спільноті, за останні десятиліття імідж держави набув ще більшого значення. Найбільший вплив мали економічні і культурні аспекти глобалізації: в сьогодення державам необхідно конкурувати у таких аспектах, як залучення іноземних інвестицій, ринки експорту, туризм, в той час як збільшення глобальної культури визначає бажання зберегти культурну різноманітність і підкреслити своєрідність.

Цей френомен вивчався 3 точки зору бізнесдосліджень, соціальних досліджень, психології, політології та комунікації. До важливих фракторів належить оцінка національної економіки, політична система, рівень освіти та компетенції населення та ступінь технологічного прогресу. У дослідженнях щодо брендування націй конструкція в основному визначається з точки зору загальних асоціацій з країною, наприклад визначні пам'ятки, кулінарні страви і популярні діячі спорту чи політики.

У дослідженнях міжгрупових відносин аналізуються образи країн зосередженням уваги на політичних діях, мотиваціях та здібностях, на сильних та слабких сторонах країни та її статусі ворога. У політичній науці образи країн досліджуються здебільшого з урахуванням концепції публічної дипломатії. Позитивне загальне розуміння репутації країни в міжнародній системі збільшуе здатність політичних дій держави.

Імідж країни має неоціненний влив на міждержавні відносини. Поряд 3 етнічними стереотипами в системі міжнародних відносин, міжкультурних комунікацій та міжнародному культурному обмеженні досить важливе місце займає зовнішньополітичний імідж держави. Привабливий імідж держави надає вагомий ряд конкурентних переваг, таких як: освіта та наука (i, як наслідок, покращення життя громадян), здатність знаходити контакти у всіх copepax культурного та суспільного життя, фрормування позитивного психологічного настрою громадян та суспільства в цілому.

За часів глобалізації та медіатизації країни все частіше підлягають спостереженню 3 боку глобальних 3МI та публіки: їх оцінюють та порівнюють відповідно до їх економічних показників, розвитку, політичної стабільності, ефективності та моральності, міжнародної політики або привабливості їх культури. Імідж країни має очевидний вплив на успіх бізнесу, торгівлі, туризму та дипломатичних відносин, оскільки це впливає на поведінку центральних зацікавлених сторін за кордоном.

Існуе досить багато підходів до формування визначення зовнішньополітичного іміджу кра- 
їни. Згідно з визначенням Всесвітньої туристської організації (UNWTO), зовнішньополітичний (міжнародний) імідж країни - це сукупність емоційних і раціональних уявлень, що випливають із зіставлення всіх ознак країни, власного досвіду, чуток, що впливають на створення певного образу [12, с. 13-14].

Міждисциплінарний огляд літератури показуе, що образи країн, спричинені соціальними та психологічними процесами, мають безліч можливих економічних, культурних та політичних наслідків. Це призвело до досліджень у дуже широкому спектрі наукових областей.

На перший погляд, образ країни асоціюеться 3 атрибутами суспільної культури, ландшафтами країни. Можна ще більше дифреренціювати його, додавши вимір, який фріксує переконання щодо естетичних якостей країни, тобто іï краси та привабливості як культурно-мальовничого місця [12, с. 16-17].

Варто визнати, що нащіональний імідж залежить не лише від повідомлень у ЗМІ чи політики, виступів, але також пов'язаний 3 продуктами та послугами країни. Транснаціональні корпорації відіграють важливу роль у брендингу націй. У свою чергу, покращений національний імідж може забезпечити сприятливіші умови для туризму, міжнародної торгівлі, міжнародного ринку праці та політичних відносин. Окрім помітності, позитивний чи негативний імідж іноземної країни в ЗМІ США маж значний вплив на ставлення громадськості до цієї країни.

Досить великого значення при побудові дійсного робочого іміджу грає саме той фрактор, як держава бажає визначити своє місце на світовій арені, та які асоціації бажає викликати. Тут імідж-мейкери мають прописати позиціонування країни як кінцеву ланку побудови іміджу. Для суб'єкта міжнародних відносин необхідно визначитися з якою метою він бажає просувати себе, та не менш важливо, як саме він буде виконувати дане завдання. Позиція держави як реакція на світові зміни, у призмі міждержавних відносин, та реакція на внутрішньополітичні метаморфози є невід'ємною частиною побудови та підтримання вже існуючого іміджу.

Таким чином, при виробленні та реалізації іміджевої стратегії, необхідно поєднувати і засоби країнового брендингу, і інструменти публічної дипломатії, щоб ефективно управляти комунікацією з представниками цільових аудиторій, а потім, залучаючи їх до спільної діяльності, переходити до двосторонньої комунікації, збільшуючи шанси на успіх.

Все вказуе на те, що у світі розпочались процеси цілеспрямованого управління сприйняттям, встановлення порядку денного, вироблення довіри та створення нового іміджу, де задіяна безліч акторів, встановлені цілі (довго- та короткострокові) та використовуються різні засоби (відкриті та закриті). Американці називають це стратегічним спілкуванням. Наприклад, вони вважають, що успішна стратегічна комунікація та публічна дипломатія має бути націлена як на масову аудиторію, так і на конкретні групи, які впливають на рішення та думки в міру свого досвіду, позиції та можливостей керівництва (наприклад, політичні та бізнес-лідери, духовен- ство, відомі журналісти, представники науковоосвітньої спільноти, жіночих організацій тощо).

Публічна дипломатія (включаючи культурну, спортивну, музейну та медіа-дипломатію) в основному використовуеться для досягнення довгострокових цілей та відкритих засобів. Візуальні та, що важливіше, виміри подій у реальному часі доповнюють словесні комунікації з метою посилення едекту. Наступна характеристика стосується аудиторіі: вона розширюеться і перетворюється 3 місцевої на глобальну (не тільки хто що говорить, коли і як важливо, але також і на кого воно орієнтоване). Легітимність, довіра, репутація, лідерство, особи, популярні настрої, страхи та очікування, символи, ідентичність і навіть сама історія стають незамінними засобами в цьому процесі [3, с. 15, 19-20].

Звертаючись до технологій формування зовнішньополітичного іміджу країни, варто, спершу звертати увагу на передумови й обставини, ресурси (ці перші елементи вказують на те, що має країни для побудови іміджу) та інтереси держави, заради реалізащї яких вона конструює свій імідж. П. Петров визначає декілька груп фракторів, що впливають на формування іміджу. До першої групи він відніс: природно-ресурсний потенціал, національне та культурне надбання, постійні геополітичні фрактори, історію країни, форма держави. До другої - групи соціологічних факторів впливу - зарахував соціально-психологічний настрій у суспільстві, форми суспільно-політичної інтеграції народу, структура, характер та принципи діяльності суспільно-політичних об'єднань, морально-етичні аспекти розвитку суспільства. До третьої - інституційні фрактори: стійка економіка, яка оцінюеться комплексом показників динаміки валового внутрішнього продукту, рівнем доходів на душу населення, об’ємом інвестицій, що залучаються, гарантією прав та свобод суб'єктів економічної діяльності, правовий простір країни та його відповідність до світових норм, ефрективність державного регулювання у всіх сфрерах [10, с. 92].

Враховуючи сукупність всіх цих фракторів - а кожна країна має свій набір цих фракторів, які мають різний ступінь впливу на фрормування іміджу країни - не існуе чітко визначених технологій для формування зовнішньополітичного іміджу країни. Крім того, сам термін «імідж» доволі складний та різноманітний, що також ускладнюе розуміння чіткої структури іміджу країни. Наприклад, Т. Грінберг визначає певний алгоритм формування зовнішньополітичного іміджу держави, який, у певному сенсі, є універсальним для іміджевої політики і включає в себе три основні етапи їі розробки: є оцінка ситуацї̈ (дослідження та аналіз, які мають в першу чергу фокусуватися на визначенні потреб аудиторії, вивченні параметрів іміджу (власних уявлень суб'єкта) та поточного образу суб'єкта, тобто тих уявлень, що сформовані у різних аудиторіях); позиціонування, яке полягає у пошуку та демонстращії відмінної, індивідуальної переваги серед інших суб'єктів (наприклад, такі типи позиціонування: за перевагою суб'єкта, кращого для цільової аудиторії, протиставлення певним групам суб'єктів, позиціонування проти конкретних конкурентів, позиціонування за асоціацією або 
проблемам); вибір та розробка колунікативних стратегій просування характеристик іліджу $\epsilon$ наступним етапом його формування (це взаємодія із засобами масової індрормащіі) [10, с. 93].

Але навіть при плідній та ефективній реалізації вже зазначених етапів, не можна забувати про те, що вже сорормований імідж треба постійно підтримувати і при необхідності корегувати, тобто це не одноденний та не одноразовий процес - постійна кропітка праця.

Не останню роль у формуванні іміджу країни грають стереотипи, що створенні навколо неї, тому бажано бути в курсі того, як сприймають країну на міжнародній арені і чи є стереотипи, які варто виправляти.

А. Осмоловська зазначає, що існують і зовнішні чинники, які мають можливості безпосередньо чи опосередковано впливати на dpopмування образу країни: міжнародні екологічні рухи та правозахисні організацї̈, які поширюють матеріали про порушення у сфрері екології, якості життя та дотримання прав людини. Так, позищія тіеї чи іншої держави щодо цих питань стає вкрай важливою, а іноді і навіть вирішальною у формування позитивного чи негативного образу; громадяни, шо проживають за кордонол (діаспори, мігранти), які фрормують образ країни, пропагуючи певні цінності, національні традиції. Вони об'єднуються в групи та мають вплив на сприйняття держави; туризл підвищує рівень обізнаності громадян тих чи інших держав, затирає кордони та $є$ величезним джерелом прибутку. Крім того, численні туристи формують чи закріплюють сприйняття держави, iï образ на міжнародній арені; діяльність дипломатичних представництв, інших зовнішньополітичних відолств та культурно-просвітницьких иентрів за кордоном, які здійснюють міжнародні обміни, репрезентують державу, відстоюють державні інтереси та інтереси і права своїх громадян; політичні технології, які дають змогу свідомо трансформувати та конструювати образ держави в заданому напрямі. Вони можуть формувати привабливі іміджі держави у певних copepax діяльності (наприклад, туризм, освіта) i сприяти трансформації міжнародного образу держави загалом [7, с. 84-85].

Щодо прикладу, то для покращення зовнішньополітичного іміджу України О. Омельченко рекомендуе виокремити декілька напрямів џілеспрямованого впливу на іноземну аудиторію: налагодження й зміцнення співпраці в культурній, науковій, інформаційній сфрері 3 провідними країнами; інформаційне забезпечення зовнішньої політики; налагодження контактів із співвітчизниками за кордоном; правозахисна й історико-архівна діяльність, важлива для позитивного сприйняття демократичним европейським суспільством; популяризація української мови та культури [8, с. 85].

Якщо ж звернемо увагу на актуалізащію питання зовнішньополітичного іміджу України після подій 2014 р., то Г. Піскорська і Н. Яковенко стверджують, що оскільки Україна виявила спроможність до збройного супротиву агресору, виявляючи патріотизм, відданість громадянського суспільства ідеям державної незалежності, це робить можливим формування позитивного іміджу України за умови внутрішньої консолідації, кардинальних редорм та зовнішньої підтримки [11].

Хоча варто зазначити, що загальної стратегії по фрормуванню і впровадженню іміджу України за кордоном поки що не сорормульовано, що робить образ України за кордоном нечітким та погано зрозумілим, а відтак не відбувається, наприклад, сплеску в туристичному або інвестиційному напрямках, хоча всі необхідні ресурси і передумови Україна для цього має.

Висновки. Підсумовуючи результати нашого дослідження, слід зазначити, що існує велика кількість фракторів, що впливають на фрормування зовнішньополітичного іміджу країни. Серед них: природно-ресурсний потенціал, соціологічні фрактори впливу та інституційні фрактори (імідж представника держави, якість та стиль проведення зовнішньої та внутрішньої політики, політика урядів щодо вирішення глобальних проблем). Загального алгоритму, тобто схеми, яка б надала можливості кожній країні побудувати свій зовнішньополітичний імідж - не існуе, адже кожна країна має свої висхідні параметри: зовнішні і внутрішні чинники, які впливають на фрормування іміджу.

В той самий час, кожному актору міжнародних відносин необхідно враховувати усі аспекти впливу на репутащію країни. У випадку покращення зовнішньополітичного іміджу у всіх напрямках можна заручитися підтримкою міжнародної спільноти, спровокувати надходження капіталу в середину країни, розвивати сферу туризму, та налагодити багатовекторну зовнішню політику.

Щодо України, то їі імідж дещо покращився після агресії Росії, оскільки вона змогла виявити спроможність до збройного супротиву, громадяни виявляли патріотизм та відданість ідеям державної незалежності, хоча це було тимчасове явище, адже загальної стратегії щодо розробки та впровадження позитивного зовнішньополітичного іміджу України ще не розроблено і , відповідно, не втілено у життя.

\section{Список літератури:}

1. Барна Н.В. «Іміджелогія». URL: http://www.dut.edu.ua/uploads/l_1776_66617386

2. Бурлина М.В. Развитие туризма как фрактор формирования имиджа территории. Межвузовский сборник научных трудов. URL: https://tourlib.net/statti_tourism/burlina.htm

3. Публичная дипломатия: Теория и практика : Научное издание / Под ред. М.М. Лебедевой. Москва : Издательство «Аспект Пресс», 2017. 272 с.

4. Гурковський B.I. Захист іміджу Української держави в умовах інформаційної глобалізації. URL: http://academy.gov.ua/ej/ej16/txts/12GVIUIG.pdf

5. Имиджелогия : учебное пособие для бакалавров / [ под ред. Н.В. Ушакова, А.Ф. Стрижова]. 3-е изд., исправл. Москва : Издательско-торговая корпорация «Дашков и К», 2010. 264 с.

6. Інформаційна політика України: европейський контекст : монографія / Л.В. Губерський, Є.Є. Камінський, Є.A. Макаренко та ін. Київ : Либідь, 2007. 360 c. URL: https://westudents.com.ua/glavy/52171-bazov-chinnikiformuvannya-nformatsyno-poltiki-ukrani.html 
7. Осмоловська А.О. Чинники формування образу країни на міжнародній арені. Політичне життя. 2018. № 2. C. $82-85$.

8. Омельченко О.А. Механізми формування політичного іміджу України. Науковий журнал «АОГОГ. Мистецтво наукової думки». 2019. № 3, квітень. С. 84-86.

9. Пантелейчук I.В. Місце та роль зв'язків з громадськістю у формуванні іміджу державних інституцій. URL: http://nbuv.gov.ua/UJRN/Tpdu_2009_4_8

10. Петров П.Г. Технології формування та підтримки зовнішньополітичного іміджу держави. Грані. № 3(131), березень 2016. С. 91-94.

11. Піскорська Г.А., Яковенко Н.Л. Імідж України в контексті російсько-українського конфолікту. URL: http://journals.iir.kiev.ua/index.php/pol_n/article/download/2517/2247

12. Почепцов Г.Г. Имиджелогия. 4-е изд. Москва : Рефрл-бук; Київ : Ваклер, 2004. 576 с.

13. Чечель О.Ю. Формування іміджу держави на міжнародній арені. Інвестииї̈: практика та досвід. 2016. № 10 . C. $82-86$.

14. Anholt S. The importance of national reputation. In J. Welsh \& D. Fearn (Eds.). Engagement: Public diplomacy in a globalized world. London: Foreign and Commonwealth Office, 2008. P. 30-43.

15. Bennett W.L., Paletz D. (Eds.). Taken by storm: The media, public opinion, and U.S. foreign policy in the Gulf War. Chicago : University of Chicago Press, 1994. 328 p.

16. Boulding K.E. The image: knowledge in life and society. Ann Arbor, MI : University of Michigan Press, 1956.175 p.

17. Brewer M., McCombs M. Setting the community agenda. Journalism \& Mass Communication Quarterly. 1996. 73(1). P. 7-16.

18. Carroll C.E. How the mass media influence perceptions of corporate reputation: Exploring agenda-setting effects within business news coverage. (Unpublished doctoral dissertation). The University of Texas, Austin. 2004. URL: https://repositories.lib.utexas.edu/bitstream/handle/2152/2153/carrollce30855.pdf

19. Carroll C.E., McCombs M. Agenda-setting effects of business news on the public's images and opinions about major corporations. Corporate Reputation Review. 2003. 16(1). P. 36-46.

20. Carter R.F., Stamm K.R., Heintz-Knowles K. Agenda-setting and consequentiality. Journalism Quarterly. 1992. 69. P. 868-877.

\section{References:}

1. Barna, N.V. «Imageology». URL: http://www.dut.edu.ua/uploads/1_1776_66617386

2. Burlina, M.V. Development of tourism as a factor in the formation of the image of the territory. Interuniversity collection of scientific papers. URL: https://tourlib.net/statti_tourism/burlina.htm

3. Public Diplomacy: Theory and Practice: Scientific Edition (2017) / Ed. M.M. Lebedevoy. Moscow: Publishing house "Aspect Press", 272 p.

4. Hurkovs'kyy, V.I. Protection of the image of the Ukrainian state in the conditions of information globalization. URL: http://academy.gov.ua/ej/ej16/txts/12GVIUIG.pdf

5. Imageology: a textbook for bachelors (2010) / [ed. N.V. Ushakova, A.F. Strizhova]. 3rd ed., Revised. Moscow: Publishing and Trade Corporation «Dashkov and K», $264 \mathrm{p}$.

6. Information policy of Ukraine: European context: monograph (2007) / L.V. Gubersky, E.E. Kaminsky, E.A. Makarenko and others. Kyiv: Lybid, 360 p. URL: https://westudents.com.ua/glavy/52171-bazov-chinnikiformuvannya-nformatsyno-poltiki-ukrani.html

7. Osmolovska, A.O. (2018) Factors of image formation of the state on international arena. Political life, 2, pp. 82-85.

8. Omel'chenko, O.A. (2019) Mechanisms of formation of political image of Ukraine. Scientific journal « $\Lambda O \Gamma O \Sigma$. The Art of Scientific Thought", no. 3, April 2019, pp. 84-86.

9. Panteleychuk, I.V. The place and role of public relations in shaping the image of state institutions. URL: http://nbuv.gov.ua/UJRN/Tpdu_2009_4_8

10. Petrov, P.H. (2016) Technologies of development and support of the foreign image of the state. GRANI, no. 3(131), March 2016, pp. 91-94.

11. Piskorska, G.A., Yakovenko, N.L. Image of Ukraine in the context of the Russian-Ukrainian conflict. URL: http://journals.iir.kiev.ua/index.php/pol_n/article/download/2517/2247

12. Pocheptsov, G.G. (2004) Imageology. 4th ed. Moscow: Refl-book; Kiev: Vakler, 576 p.

13. Chechel, O.U. (2016) Formation of the State Image in International Dimension. Investments: practice and experience, 10 , pp. 82-86.

14. Anholt S. (2008) The importance of national reputation. In J. Welsh \& D. Fearn (Eds.). Engagement: Public diplomacy in a globalized world. London: Foreign and Commonwealth Office, pp. 30-43.

15. Bennett W.L., Paletz D. (Eds.) (1994) Taken by storm: The media, public opinion, and U.S. foreign policy in the Gulf War. Chicago: University of Chicago Press, 328 p.

16. Boulding K.E. (1956) The image: knowledge in life and society. Ann Arbor, MI: University of Michigan Press, 175 p.

17. Brewer M., McCombs M. (1996) Setting the community agenda. Journalism \& Mass Communication Quarterly, 73(1), pp. 7-16.

18. Carroll C.E. (2004) How the mass media influence perceptions of corporate reputation: Exploring agenda-setting effects within business news coverage. (Unpublished doctoral dissertation). The University of Texas, Austin. URL: https://repositories.lib.utexas.edu/bitstream/handle/2152/2153/carrollce30855.pdf

19. Carroll C.E., McCombs M. (2003) Agenda-setting effects of business news on the public's images and opinions about major corporations. Corporate Reputation Review, 16(1), pp. 36-46.

20. Carter R.F., Stamm K.R., Heintz-Knowles K. (1992) Agenda-setting and consequentiality. Journalism Quarterly, 69, pp. 868-877. 